Portland State University

PDXScholar

$5-24-2018$

\title{
Food Security and the Sustainable Livelihood Approach to Development in Uganda
}

Megan Jessup-Varnum

Follow this and additional works at: https://pdxscholar.library.pdx.edu/honorstheses Let us know how access to this document benefits you.

\section{Recommended Citation}

Jessup-Varnum, Megan, "Food Security and the Sustainable Livelihood Approach to Development in Uganda" (2018). University Honors Theses. Paper 556.

https://doi.org/10.15760/honors.562

This Thesis is brought to you for free and open access. It has been accepted for inclusion in University Honors Theses by an authorized administrator of PDXScholar. Please contact us if we can make this document more accessible: pdxscholar@pdx.edu. 
Food Security and the Sustainable Livelihood Approach to Development in Uganda

\author{
by \\ Megan Jessup-Varnum
}

An undergraduate honors thesis submitted in partial fulfillment of the requirements for the degree of
Bachelor of Arts
in
University Honors
and

International \& Global Studies: International Development

Thesis Adviser

Leopoldo Rodrigues, Ph.D

Portland State University

2018

Abstract 
Food security is a growing global issue. Poverty and malnutrition kill millions of people worldwide every year. Sub-Saharan Africa has the highest rates of poverty and malnutrition in the world. Previous development strategies in sub-Saharan Africa that have attempted to alleviate poverty and eradicate malnutrition have proved unsuccessful. However, there is a fairly new approach to development, known as the sustainable livelihood approach that tackles issues of poverty, malnutrition, and food security in a holistic way. This paper explores the sustainable livelihood approach to development and it's effectiveness. This paper focuses on a health clinic and rabbit breeding program in Southwestern Uganda that has a sustainable, innovative, and integrated approach to development. This paper argues that holistic livelihood programs have great potential to sustainable development.

\subsection{Introduction}

Household food security is an issue that affects populations around the world. Every night, 815 million people go to bed hungry even though there is more than enough food produced daily to feed the global population. (FAO, 2017). Ninety-eight percent of those suffering from hunger live in the developing world. (Oxfam Canada, n.d.) Ironically, developing countries are some of the largest food producers in the world. However, the farmers and their families who produce food for the rest of the global population face massive barriers to food security.

As the global population has grown, agricultural production has kept up with a growing demand. Oxfam notes, "The world produces 17 percent more food per person today than 30 years ago. The problem is that many people in the world don't have sufficient land to grow, or income to purchase, enough food (Oxfam Canada, n.d.)." It is clear that food security the result of more than just food availability. Studies show that rising production may not have any impact on people's access to food, and does not take into account the quality of food accessed or consumed (Burchi, Frizon, \& Fanzo, 2011).

"Food security strategy should be based on the premise that food insecurity derives from failure of access to food rather than international or national food shortage" (Thompson, 2001). Poverty is perhaps the biggest driver of food insecurity. "Food security becomes an aspect of poverty, or failure of entitlements, rather than being about inadequate food production" (Thompson, 2001). Addressing food security requires a more holistic approach than just food production. The FAO defines four dimensions of food security, all of which must be fulfilled simultaneously in order to achieve food security.. The four dimensions are: 1) physical availability of food, 2) economic and physical access to food, 3) food 
utilization, and 4) the stability of those other dimensions over time (FAO, 2008). Figure 1 explains the four dimensions of food security according to the FAO.

Figure 1. Food and Nutrition Security. From The role of food and nutrition system approaches in tackling hidden hunger by Burchi, F., Fanzo, J., \& Frison, E., (8 February, 2011). Retrieved from httnc $\cdot / / \mathbf{x} / \mathbf{x} / \mathbf{x} / \mathrm{n}$ hi nlm nih onv/nuhmed/71556101

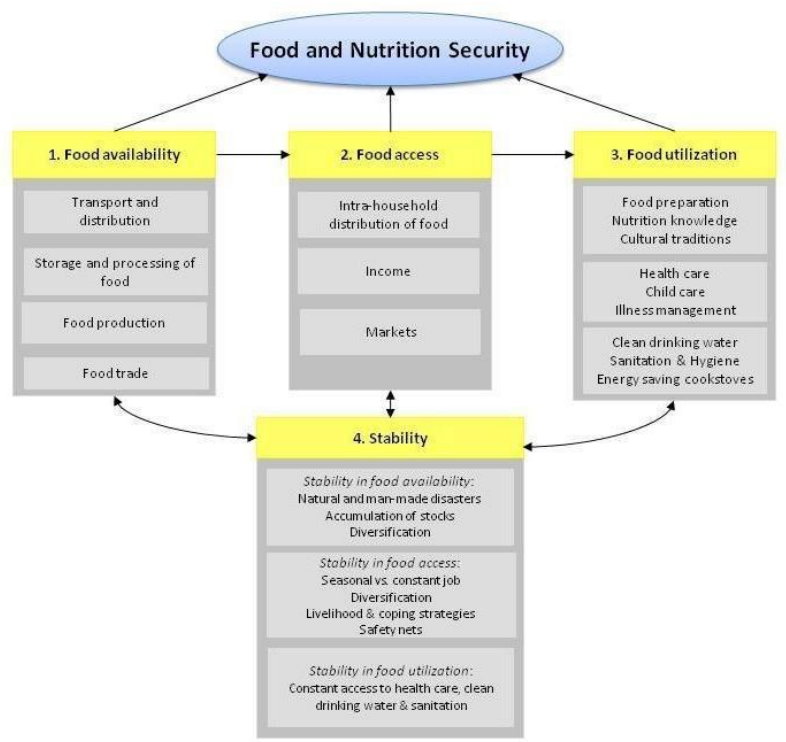

Securing food for the growing global population has been a topic in development studies for many years. In 1996, The World Food Summit Declaration defined food security as "all people at all times have physical and economic access to sufficient, safe and nutritional food to meet dietary needs and food preferences for an active and healthy life" (Thompson, 2001). Food security is a vital aspect to a household's livelihood. When families and communities face economic, environmental, and social 
insecurity, their food security is put in jeopardy. Since food is a basic requirement for survival, households prioritize accessing food (or at least a form of calories) before other things such as education, household items, and clothing. In 2016, the United Nations Development Program created 17 Sustainable Development Goals (SDGs). The first two goals are to end poverty and hunger by 2030. While, this will be a challenge, this paper addresses how to sustainably address issues of poverty and hunger concurrently.

This paper focuses on food security and rural livelihood development, specifically in Uganda. Rural development is crucial for eliminating global poverty and hunger because the majority of people living in poverty live in rural communities. Addressing issues of poverty, hunger, and rural development is particularly important for Uganda because over 80 percent of the population lives in rural communities (Feed the Future, 2018). This paper argues that a holistic livelihood approach to development can bring positive and sustainable change and development to rural communities. Within the broader subject of livelihood security, this paper specifically looks at food security at the household level, which, in addition to being a basic human right is also a basic tool of development because securing food for a household can lead to further improvements in a household's wellbeing.

\subsection{Methodology}

This paper draws on knowledge from peer reviewed journals and books in order to discuss historical events and development theories. This paper also includes a case study which explores Kigezi Healthcare Foundation (KIHEFO), a non-profit, community-based health clinic in rural Southwestern Uganda. Jessup-Varnum worked as an intern with KIHEFO from January to March 2018. During that time, she observed the role of the clinic in it's community and worked alongside doctors and clinicians in providing medical care and rural development in Southwestern Uganda. Jessup-Varnum was highly involved with KIHEFO's food security initiative, which promotes rabbit breeding among rural households. In addition to her work with KIHEFO, Jessup-Varnum conducted interviews with six rabbit beneficiaries and seven KIHEFO staff members in order to understand the program. Prior to interviewing beneficiaries and staff, Jessup-Varnum obtained Institutional Review Board approval from Portland State University. The information gathered from those interviews is used in the case study of this paper.

\subsection{Description}

The purpose of this paper is to answer the question: "How can livelihood programs improve rural food security in Uganda?" Uganda was chosen as the location of this study based on Jessup-Varnum's internship. This country is particularly relevant when considering issues of food security based on its geographical location in sub-Saharan Africa, where there is a high prevalence of food insecurity. This paper first looks issues of food and livelihood security in the sub-Saharan Africa region, and then 
specially in Uganda. Next, it addresses previous development strategies and why they were not as successful as they were intended to be. Then, it looks at sustainable development and its effectiveness. Within the context of sustainable development, this paper proposes the sustainable livelihood approach to development as a comprehensive approach with positive outcomes. Finally, KIHEFO's organizational structure; and the work it is doing in its community is presented as a case study. Drawing on JessupVarnum's field research and peer-reviewed research by other scholars their rabbit breeding program is discussed. Lastly, this paper examines how KIHEFO's model fits within the sustainable livelihood approach to development.

\subsection{Background}

\subsection{Food Security in Sub-Saharan Africa}

As the global population increases, the question of how to feed the growing number of people becomes more salient. In 2016, the number of undernourished people in the world increased to an estimated 815 million, up from 777 million in 2015 but still down from about 900 million in the year 2000 (FAO, 2017). Issues of hunger and food security will only be exacerbated as the global population moves toward 10 billion people living on the earth in 2050. It is estimated that food and feed production will need to be tripled in order to keep pace with the projected human population (Lukefahr, 2004). While tripling food and feed production is increasingly challenging due to global climate change, it is not the only issue. The four aforementioned dimensions of food security: food access, availability, utilization, and stability also need to be addressed.

Issues concerning food insecurity and poverty are especially prevalent in Sub-Saharan Africa. According to the World Hunger Organization (2016), "there has been the least progress in the subSaharan region, where more than one in four people remain undernourished - the highest prevalence of any region in the world". This is significantly higher than global statistics on food security. Between 2014 and 2015, approximately 7.5 percent of the world population experienced extreme food insecurity (LIFT, 2013). According to Baro and Deubel (2008), "Sub-Saharan Africa is the only region of the world in which chronic food insecurity and threats of famine remain endemic for most of the population and the number of malnourished people is steadily increasing". This global disparity in malnourishment must be addressed in a sustainable way in order to promote development in Sub-Saharan Africa.

\subsection{Food Security in Uganda}

Uganda has exceptionally high levels of malnutrition and food insecurity. The U.S. Government's global hunger and food security initiative, known as Feed the Future, has done extensive research on food 
security and malnutrition in Uganda. In 2018, Feed the Future found that, "over 30 percent of the total population faces some level of chronic food insecurity and malnutrition, which directly or indirectly contributes to 60 percent of child mortality." Ironically, Uganda is known as the potential breadbasket of East Africa because of its fertile ground. "Uganda is rich in natural resources and thanks to favorable climatic conditions a great variety of crops can be grown" (Martiniello, 2015). Uganda needs to find better ways to utilize it's agricultural sector and develop rural communities in order to solve their issues of food security and malnutrition.

Despite agricultural shortcomings, farming is still at the heart of Uganda's economy. In 2016, Uganda saw GDP growth of $4.6 \%$ and agriculture accounted for $24.4 \%$ of that growth (Feed the Future, 2018). Yet most of the crops cultivated in rural areas are kept for home consumption, with an "average $72 \%$ of cooking bananas, $59 \%$ of maize, and between $65 \%$ and $95 \%$ of other food crops are retained for home consumption, implying consequently low output proportions reaching the market" (Ellis and Bahiigwa, 2003). This reveals that subsistence agriculture is a widespread livelihood strategy for household food security.

The majority of those who engage in agricultural practices live in rural communities. According to Feed the Future (2018), 83.6\% of Uganda's population lives in rural areas. Livelihood practices in rural Uganda are rudimentary, and many strive to migrate to urban settings where there are more resources and opportunities. Seventy-five percent of the rural population is engaged in agriculture-based livelihoods and women produce some $80 \%$ of the food consumed nationally (Martiniello, 2015). Uganda is a patriarchal society in which women and men have very different roles. Women typically work in the farm or garden while men engage in more "modern" activities in towns. Given that the majority of the population lives in rural areas, rural development must be given priority. Rural development which integrates agriculture to other livelihood activities has the potential to make the greatest impact on these communities since many people partake in farming.

In addition to malnutrition, one of the biggest public health issues in Uganda is HIV/AIDS. Food insecurity is compounded by HIV/AIDS, especially in rural, resource-limited communities. Having HIV/AIDS; limits some people's ability to secure food. Tsai et. al (2011) argue, "HIV/AIDS and food insecurity are two of the leading causes of morbidity and mortality in sub-Saharan Africa, with each heightening the vulnerability to, and worsening the severity of, the other". This is especially true in Uganda, where $6.7 \%$ of the population is HIV positive and nearly $80 \%$ of those infected with HIV are between the ages of 15 and 45. That age range is also the most economically productive age and HIV positive people tend to be the family breadwinner (Bukusuba et al., 2007). In fact, HIV/AIDS and food insecurity negatively influence each other. "Lack of food security and poor nutrition status may hasten progression to AIDS-related illnesses, undermine adherence and response to antiretroviral therapy and 
exacerbate socioeconomic impacts of the virus. HIV infection itself undermines food security and nutrition by reducing work capacity and productivity and jeopardizing household livelihoods" (UNAIDS, 2008). Food security helps those living with HIV lead a better life because they have higher energy requirements. "Adults living with HIV have 10-30\% higher [caloric] requirements than a healthy adult without HIV, and children living with HIV 50-100\% higher than normal requirements." (UNAIDS, 2008).

\subsection{Previous Development Strategies in Uganda}

The World Bank and the International Monetary Fund (IMF) are the two leading organizations who give loans to developing countries. Since they are primarily funded by the U.S., these loans typically follow a Western agenda, which does not necessarily fit with what is needed in the communities which receive the aid. Both of these organizations have conditions for loans to be released. These conditions, known as Structural Adjustment Programs (SAPs) are designed to shift social and economic structures in the countries receiving the loans (Smallman \& Brown, 2015). The required shift in economic structures is specifically intended to ensure debt repayment. According to Shah (2013), "SAPs have required poor countries to reduce spending on things like health, education and development, while debt repayment and other economic policies have been made the priority". Ultimately, the social and economic restructuring that SAPs require disrupt systems that are already in place. While that is the intention in some cases, in other cases it leads to negative consequences. In Uganda, “accessibility to social services has worsened since the implementation of [SAPs]" (Ssewanya and Ahamdi-Esfahani, 2010). Reduced spending on social services typically leads to long-term negative consequences and a decline in the social wellbeing of citizens.

Policies of structural adjustment have led to poverty and underdevelopment in many sub-Saharan

[SAPs] starved the peasant sector of capital investment and productive infrastructure, and economic liberalization exposed a small-holder sector weakened by competition from highly subsidized large-scale northern farmers, while encouraging staple food import dependency in African cities as well as migration to the sition

African countries. According to Bryceson (2009):

SAPs have disadvantaged rural populations, leaving them few options for economic empowerment. Instead of outside agencies attempting to develop communities from afar without extensive knowledge of the community being developed, development practices need to come from those who understand the communities of these places. In terms of food security, Ssweanya and Ahmadi-Esfahan (2010) claim that 
there can be "no effective policy developed without knowledge of the dimensions of the food insecurity problem at the household level". A holistic understanding of a community can lead to more comprehensive development strategies, and can work to address multiple issues rather than isolating and prioritizing one need. This can lead to a more effective and sustainable development strategy.

SAPs and other development projects with neoliberal agendas have failed in Uganda. By implementing trade liberalization, they have damaged social, economic, and environmental structures. This can be seen especially in the agricultural sector, which is dominated by subsistence farmers in developing countries. Andersson and Gabrielsson (2012) write,

The failure of earlier solutions to the problem of food insecurity in the 1970s and 1980s was largely attributed to their technological and economic growth bias, stressing the significance of intensification of production and the sale of surpluses rather than equitable distribution, access, affordability and utilization. Since then, it has become clear that food security is a highly complex issue, encompassing a wide range of interrelated environmental, social, SAPs favor agricultural exports as opposed to subsistence agriculture. "Uganda has more than enough food to meet its domestic demand, and this has partly led to promotion of non-traditional exports such as beans and maize" (Ssewanya and Ahamdi-Esfahani, 2000, 94). In the 1990s, food production and food sales increased in Uganda. However, this coincided with a growing problem of food insecurity among the very same producers. This suggests that famers were either not aware of their own needs or used the income from their food sales for other immediate needs such as health and education. (Apili Ejupu et at. 1999). This further demonstrates how the commercialization of agriculture has largely failed in Uganda. In a study conducted by Ssewanya and Ahamdi-Esfahani (2000), it was found that most rural households reported food sales, even those already experiencing food shortages. Here, a trade-off between food security and income is visible". The only way that commercial agriculture can work is if a household is already producing enough food for themselves and there are food stuffs left over to sell. Otherwise, it does not promote equitable distribution, access, affordability, and utilization of food, and therefore does not promote food security. Ejupu et al. (1999) claim that "Food purchases make a small contribution to food availability making food retention the better means of guaranteeing food availability rather than income diversification". Essentially, subsistence agriculture is more effective at promoting food security than commercial agriculture. According to Ssewanya and Ahamdi-Esfahani (2000) "Uganda appears to be a prime example of a country where national food self-sufficiency and strong economic growth have not 
translated into food security, particularly in rural areas". It is more sustainable and cost-effective to grow your own food than to buy other foodstuffs with the income earned from food sales.

Uganda, which has rich and fertile land, has not been able to capitalize on its agricultural sector as a result of poor development strategies. Although the majority of Uganda's agricultural sector is subsistence based, development strategies have attempted to modernize agriculture and emphasized commercial agriculture. However, this is challenging since large-scale, modern agriculture requires significant amounts of land and external inputs. As a result, small-scale farmers have been unable to compete with large-scale commercial farms and have been left out of the market. Large-scale producers are able to sell greater amounts of food stuffs for lower prices. Furthermore, Martiniello (2015) notes that, "Postcolonial neoliberal development has produced absolute de-peasantization and displacement". As rural livelihoods fail and people find themselves desperate, rural to urban migration increases.

Rural to urban migration further isolates those living in rural communities. It also leaves fewer people in rural communities who are able to work in the fields and produce food. Households are often disadvantaged by having fewer laborers to work their land. While in theory remittances from urban dwellers to family members in rural communities subsidizes the loss of workers, finding work in cities is not always guaranteed. According to the Uganda Bureau of Statistics (2018), 16.4\% of youth between the ages of eighteen and thirty are unemployed. Ahaibwe \& Mbowa (2014) found that, "Urban youth are more likely to be unemployed (12\%) than rural youth (3\%)". Rural to urban migration does not always lead to economic prosperity, which can bring up another issue of urban poverty and exacerbate rural poverty.

In an attempt to solve issues of food insecurity and malnutrition in Uganda, many organizations have focused on immediate need and given aid in the form of food assistance. For example, in the first quarter of 2018 alone, the World Food Programme distributed 11,700 metric tons of food assistance to Uganda and helped 1 million people (WFP, 2018). While this is helpful in the short-term, it is not a sustainable long-term solution to the issue of food insecurity in the country. Furthermore, this undermines local agricultural production because it lowers the price of local food.

Instead of empowering people to provide for themselves, Western donor intervention has contributed to a cycle of dependency. According to Bryceson (2009), "Ironically, much Western donor intervention over the last three decades has undermined the food producing capabilities of the African continent". Shifting towards a more participatory form of development can empower local leaders and build upon existing social practices. Instead of imposing policies and changes based on Western ideals, involving local people in their own development is gaining global recognition. Mohan (2014), notes that in the past development was equated with the modernity achieved by 'Western' societies and the ideas of 
the 'non-expert' local people was ignored. The knowledge of indigenous people must be incorporated into development practices in order to employ the most effective and sustainable strategies.

The Ugandan government and other international development initiatives have been working to improve rural livelihoods for over 20 years. In 1997, the Ugandan government proposed the poverty eradication action plan (PEAP) which contains four goals: sustainable and fast economic growth and structural transformation, "good security" and governance, increasing the ability of the poor to raise their incomes; and increasing the quality of life for the poor (Ministry of Finance, Planning, and Economic Development, 2001). Ellis and Bahiigwa (2003) deduced that PEAP encourages an increase in the cash component of household incomes from multiple sources so that, as incomes rise, rural families become less tied to the security of subsistence food production, and therefore more oriented to the production of diverse outputs for the market. The diversification of livelihoods is a common, and generally effective, development strategy. However, moving away from subsistence agriculture and towards commercial agriculture may not be feasible or beneficial in remote rural communities. A possible alternative could be the diversification of subsistence crops in order to protect against crop failure and climate change.

One aspect of PEAP is Uganda's Plan for Modernization of Agriculture (PMA). This plan, put in place in 2001, was the Ugandan government's attempt to eradicate poverty through agricultural improvements and interventions. They recognized that the poorest Ugandans lived in rural areas and relied on subsistence agriculture for their livelihoods. PMA planned to modernize and bring into the market subsistence farmers. The PMA targets both the farmer and the sector. The PMA vision is "poverty eradication through a profitable, competitive, sustainable and dynamic agricultural and agro-industrial sector" (Government of Uganda, 2001). However, this plan has largely failed because it focused entirely on the market and attempts to solve issues of rural poverty by transforming farmers into businesspeople. Failure of such a police should come as no surprise. Not only impoverished farmers lack the necessary assets, primarily capital, to do so, but no one thought of asking them in they had an interested in becoming businesspeople. A more appropriate plan would be to first improve the assets that poor subsistence farmers already use, and then commercialize the sector when they have the means to do so.

Diversification of the agricultural sector and the introduction of larger, even international, markets has the potential to lead to improved livelihoods for the rural poor in Uganda. However, the programs in place have not been properly executed and have largely failed. Programs of diversification of agriculture and modern agriculture have had very little impact on the vast majority of the rural population. This calls for a change in approaches. Instead of conditions to aid and food supplementation programs, development projects must incorporate preexisting knowledge from the communities in which they are trying to help. Bryceson (2009) proposes, "In an age of global financial crisis, perhaps African smallholders' economic wisdom directed at combining conservative staple food surgical strategies with 
highly adaptive and flexible commercial livelihoods can finally be appreciated." Essentially, subsistence agriculture should be respected and encouraged because it provides food security to those who need it the most: the rural poor. Only once food security is attained the rural poor can move towards other income generating practices. Commercialization of agriculture can be one way to generate income, but it is not the only solution. Asset generation and improvement is a far more flexible and beneficial strategy because it allows the poor to use their own skills to advance themselves in the way they see fit.

\subsection{Sustainable Development and the Livelihood Approach}

All too often, development programs simply examine the wealth and income of a household, rather than analyzing what led to such economic conditions. There are many factors that determine a household's livelihood status and economic condition. LIFT (2013) notes that,

The term livelihood is often used interchangeably with economic strengthening and refers generally to economic production, employment, and household income. A more holistic understanding of livelihood, however, incorporates this general definition within a broader context of economic development, reduced vulnerability, and environmental sustainability.

In order to be effective, development agencies must consider the latter, more holistic understanding of livelihood provided by LIFT. While economic development is important, if development does not also address vulnerability and environmental sustainability, it is likely to fail. This is especially important in rural communities where people rely on agriculture for livelihood generation. Therefore, rural livelihood development must look at people's entire array of assets, rather than just income generating assets.

Sustainable development, which poses long-term solutions, is crucial for effectively aiding rural communities. There are many definitions of sustainability that can be applied to different contexts. This paper will address sustainable livelihood development in a rural setting. According to Lukefahr (2004), sustainable development is "the need to care for the ecological, economical, and sociological consequences of development choices for present and future generation" (Lukefahr, 2004). These factors are especially important in rural development, in order to find long-term and holistic solutions.

Recently, there has been a growing emphasis on integrated development approaches which acknowledge the complexity of livelihood development. These approaches attempt to resolve underlying issues in developing countries, rather than imposing quick fixes. One holistic approach to sustainable development, which can be seen in Uganda, is known as the livelihood approach. 
The sustainable livelihood approach looks at what forms of capital a household has and how they

The [sustainable] livelihood approach was a response to the disappointing results of former approaches in devising effective policies to encourage development and/or to alleviate poverty; the central objective was 'to search for more effective methods to support people and communities in ways that are more meaningful to their daily lives and needs, as opposed to readymade, interventionist instruments

use those various forms of capital to sustain and advance themselves. According to Zoomers (2014): The sustainable livelihood approach was developed by Robert Chambers and Gordon Conway, two development scholars and practitioners. According to Chambers and Conway (1991), a livelihood comprises the capabilities, assets (stores, resources, claims, and access) and activities required for a means of living: a livelihood is sustainable which can cope with and recover from stress and shocks, maintain or enhance its capabilities and assets, and provide sustainable livelihood opportunities for the next generation; and which contributes net benefits to other livelihoods at the local and global levels in the short and long term. The sustainable livelihood approach proposes that a number of assets (financial, human, natural, physical, and social capital) are used by households to provide the necessities of its members. It also recognizes that when household needs are satisfied, local and global livelihoods also benefit. Access to assets both influence and result from policies, institutions, and processes. The more livelihood assets a household has, the more influence they are likely to have on policies, institutions and processes. For example, a businessperson who has a significant amount of financial capital will have a strong influence in the private sector. If that person is successful in the private sector, their monetary rewards will bring them more capital (or livelihood assets). Conversely, a rural farmer who has few livelihood assets would have much less influence in policies, institutions, and processes. Additionally, that farmer would likely rely on policies, institutions, and processes for livelihood assistance. 
There is a growing body of work that analyzes livelihoods and livelihood development. Zoomers

Livelihood research, analyzing in detail how rural people build their livelihoods on the basis of specific combinations of capitals (e.g. natural, financial, social, human etc.) in a particular context, helped to uncover a number of dimensions of rural livelihood that up to then had not been very clear. It helped to get a more holistic understanding of livelihood, showing that livelihood does not only concern material well-being, but rather

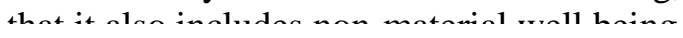

(2014) explains that,

All households, both rural and urban have different capitals that they can use to sustain and advance themselves. The majority of a rural household's capital is related to agriculture. "More than $80 \%$ of the population reside in rural areas and depend of agriculture for livelihood security including food security" (Ssewanya and Ahamdi-Esfahani, 2000). Zoomers (2014) notes that livelihood assets can be both material and non-material. Non-material well being, such as a household's level of education is as important to develop as their material well being. Developing a household's non-material wellbeing can contribute to their social human, and eventually financial capital.

The combination of livelihood capital and the policies, institutions, and processes determines a household's vulnerability context. People living in poverty typically face high levels of vulnerability. According to LIFT (2013), vulnerability is defined as "the household's susceptibility to shocks and stresses that affect the household's ability to generate sufficient income to earn a livelihood and achieve a threshold level of nutritional requirements for a healthy life both now and in the future". A household's vulnerability context includes aspects that are outside of their control, as well as aspects that the household may have some level of control over. For example, drought or floods lay outside a household's control, but irrigation and food storage systems are something a household can control. Of course, there are still aspects of irrigation and food storage systems that a household cannot control, but less so than climate conditions. Those living in remote rural communities as especially sensitive as they are isolated from institutions, policies, and processes that can help them. Additionally, as farmers, they are more susceptible to uncontrollable, outside forces, such as weather conditions. The sustainable livelihood approach offers an alternative way of analyzing food security issues because it looks at household food security both in its vulnerability context and in relationship to policy decisions. (Thompson, 2001). 
The overarching goal for development projects and organizations is to relieve or eradicate poverty. In line with it's approach to development, the sustainable livelihood approach addresses poverty in a holistic way.

There are three insights into poverty which underpin [sustainable livelihood development]. The first is the realization that while economic growth may be essential for poverty reduction, there is not an automatic relationship between the two since it all depends on the capabilities of the poor to take advantage of expanding economic opportunities. Secondly, there is the realization that poverty - as conceived by the poor themselves — is not just a question of low income, but also includes other dimensions such as bad health, illiteracy, lack of social services, etc., as well as a state of vulnerability and feelings of powerlessness in general. Finally, it is now recognized that the poor themselves often know their situation and needs best and must therefore be involved in the

According to Lasse Krantz (2001):

Unlike other development approaches, Krantz addresses how the sustainable livelihood approach is people-centered, rather than centered on economic growth. Of course, economic growth is a part of the sustainable livelihood approach, but only when paired with the skills and opportunities of the poor. Once again, we see how a household's economic condition not the only determinant of this form of development. Instead, it looks holistically at a household's assets and wellbeing. Finally, Krantz calls for participatory development when he notes how the poor must be involved in their own development. Kaag asserts that, "The livelihood approach represents a multidisciplinary view of poverty, acknowledging that poverty is not an economic problem, but that it involves political, cultural, social and ecological aspects as well" (Zoomers, 2014). Ultimately, a household's livelihood assets determine what livelihood strategies they use in order to achieve livelihood outcomes. A wealthy household may use income generating schemes to advance their livelihood, while a household living in poverty will employ coping strategies to survive. When desired livelihood outcomes are achieved, a household has greater asset security, which may help them improve other aspects of their livelihood. Additional assets reduce a household's vulnerability and lead to further livelihood development. Figure 2 below visually represents the sustainable livelihood framework. 
In order for the sustainable livelihood approach to be effective, it must be aimed at the household level. LIFT (2013) states, "Food production constitutes one of the most basic livelihood activities, and can be a critical source of food access, particularly for rural households." This is especially true in rural communities, where populations rely on agricultural production. As demonstrated in the figure above, human, financial, social, physical, and natural capitals drive the household livelihood framework. Improved food security is just one of the livelihood outcomes to be achieved when livelihood strategies are implemented. According to LIFT (2013), "Successful food security interventions need to address not

Figure 2. Household Livelihood Framework. From Livelihood \& Food Security Conceptual Framework by Gary Woller (2013). Retrieved from http://theliftproject.org/wp-content/uploads/2013/03/Livelihood-and-FoodSecuritv-Conceptual-Framework.pdf

only issues related to food security, but also wider issues related to households' livelihoods and their vulnerability context". However, household food security is an especially important aspect of livelihood programs because food security and household livelihood influence each other. 


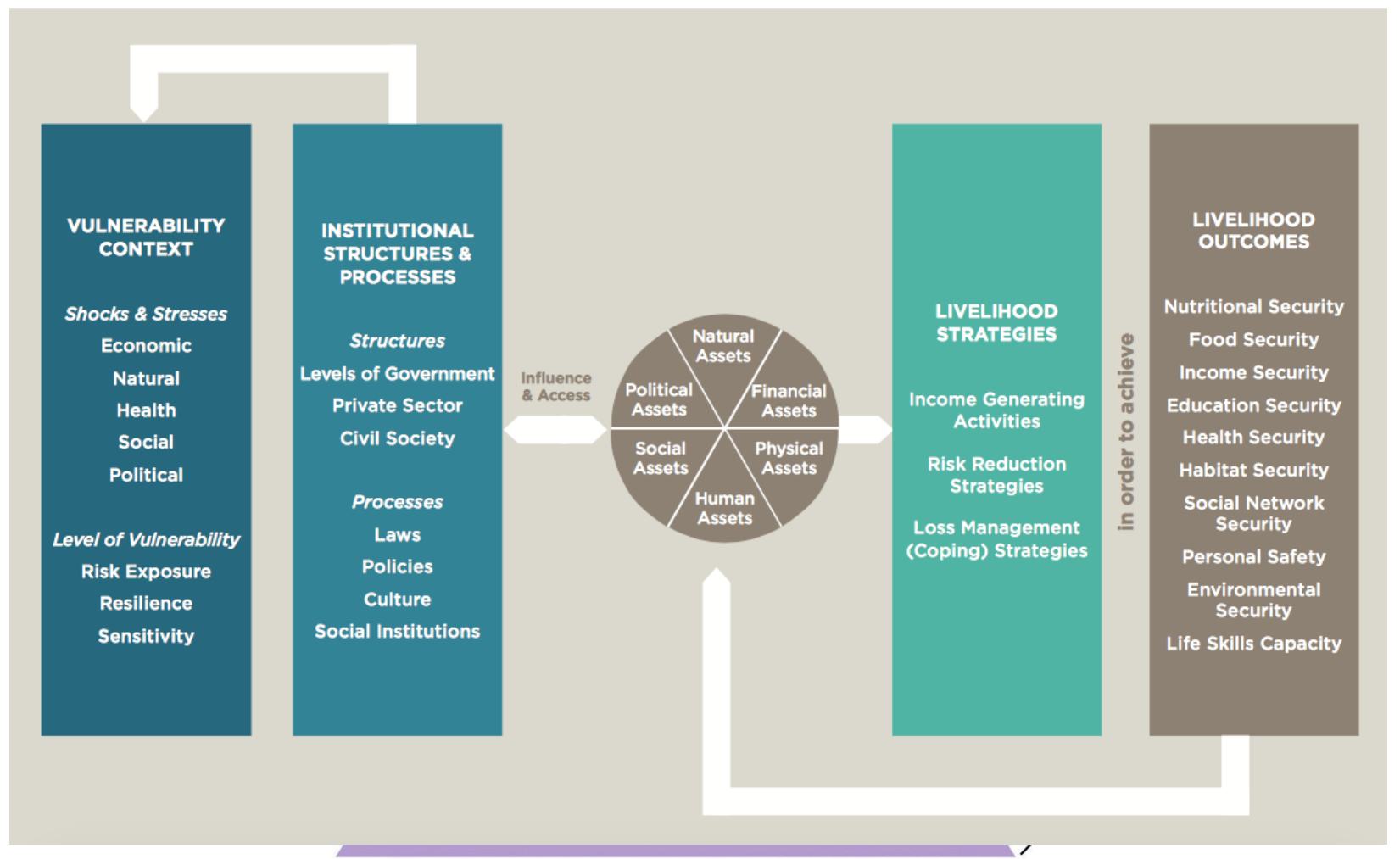

Food security is fundamentally linked to questions of livelihood (Oxfam, 2017). If food security does not exist, other livelihood outcomes will most likely fail to be reached and efforts to secure food will be prioritized. According to Maxwell (1996) "access to food by individuals in a household is pervasively linked to the control they have over household resources and the access they have to household income." Food security is more than having food on the table, it is a requirement for personal survival and advancement. Maxwell (1996) notes, "food security stands as a fundamental need, basic to all human needs and the organization of social life. Access to necessary nutrients is fundamental, not only to life per se, but also to stable and enduring social order." Food security is not only necessary for individuals, but also for society to function and progress. Due to this, food security is an essential element of the sustainable livelihood approach to development.

In 1943, American psychologist Abraham Maslow, published his theory of human motivation, now known as Maslow's hierarchy of needs. Figure 3 illustrates Maslow's hierarchy of needs. 
Figure 3. Maslow's Hierarchy of Needs. From Maslow's Hierarchy of Needs by Saul McLeod (21 May, 2018).

Retrieved from

Physiological needs (food, water, warmth, and rest) are the most basic needs that Maslow recognizes. These needs will be the major motivation for a person to achieve. According to Maslow (1943), "A person who is lacking food, safety, love, and esteem would most probably hunger for food more strongly than for anything else". In Maslow's theory, safety, belongingness and love, esteem, and selfactualization needs cannot be realized until physiological needs are satisfied. Clearly, food security is a prerequisite for other types of livelihood security. It is necessary for food security to be prioritized in the sustainable livelihood approach to development as it determines an individual's ability to develop other aspects of their livelihood.

\subsection{Case Study}

\subsection{Kigezi Healthcare Foundation}

Tucked away in the corner of Southwestern Uganda, bordering Rwanda, lies Kabale district, home to 210,000 people. Kabale is lush, green, fertile, and mountainous. Known as the "Switzerland of Africa," Kabale's terraced hills are dotted with eucalyptus trees and agriculture plots that grow subsistence crops such as Irish potatoes, bananas, pumpkin, beans and corn. Although the Kabale district is the largest agricultural producing area in Uganda, it also has one of the highest rates of malnutrition in the country. Child malnutrition is exceptionally troubling. It has been reported that " $8.6 \%$ of children in Kabale (aged 12-23 months) receive a minimum acceptable diet" (Children, Nutrition, and Food Security, n.d.). Malnourishment at such a young age can lead to stunting and chronic malnutrition.

Kigezi Healthcare Foundation, better known as KIHEFO, is a non-profit, community-based health clinic working to eradicate malnutrition in Kabale district. Dr. Geoffrey Anguyo, a native Ugandan, founded KIHEFO in 2001 when he recognized the issues of malnutrition during his clinical rotations in Kabale. KIHEFO's mission is to fight disease, poverty, and ignorance (also known as a lack of knowledge) in a sustainable, integrated, and innovative way. Due to this, KIHEFO has a number of 
projects that address health, economic, and social issues in Kabale district. Their headquarters are located in Kabale-town, the biggest, and most centrally town in the district.

I lived in Kabale-town and worked with KIHEFO from January to March 2018. During this time, I was heavily involved with various aspects of the organization, specifically their rabbit breeding project. Independently, I conducted semi-structured interviews with six rabbit beneficiaries and six KIHEFO staff members who were involved with the project. The aim of my research in Kabale was to understand why KIHEFO chose to integrate rabbit breeding into their health clinic and the potential that rabbit breeding has to improve rural household livelihoods. This case study will integrate research from scholarly journals as well as personal accounts and interviews from my work in Kabale. The aim of this case study is to demonstrate how holistic livelihood centered approaches to development are effective and sustainable.

After 17 years, Dr. Anguyo and his staff have developed unique programs that effectively represent their mission. Their approach to health care comprehensively addresses issues of disease, poverty, and ignorance in their community in a sustainable, integrated, and innovative way. The KIHEFO staff is entirely Ugandan and work passionately to solve these issues using their own knowledge of their community. Currently, KIEHFO has five clinics in Kabale-town, which focus on HIV, general health, dental health, maternal health, and nutrition rehabilitation. While these five clinics each have a specific focus, they work together to provide comprehensive care and reach the best possible outcome for their patients.

KIHEFO also holds at least seven outreach clinics each month in rural communities in order to bring health care services to those who are unable to travel. Instead, KIHEFO brings the services to them. These outreaches, which can be anywhere from a thirty minute to two hour drive outside of Kabale-town, aim to bring both medical attention and health education to people who otherwise would never receive these services. KIHEFO is the only clinic in Uganda that consistently brings medical services directly to those in need in rural communities. The number of outreaches they hold each month depends on how much funding they receive. KIHEFO's clinics are completely free for rural patients, and are funded by the Ugandan government, the U.S. government, fees from interns, and private donations (G. Anguyo, personal communication, March 6, 2018). When considering the sustainable livelihood approach, poor people living in rural areas need institutions, policies, and processes to sustain and advance themselves. By providing outreach services to communities in need, KIHEFO is improving their assets.

There is a high demand for KIHEFO's healthcare services because KIHEFO is the only clinic providing continuous services. While I was in Kabale, there were between 100 and 700 patients at each outreach I attended. Although the communities vary, the ailments from patients are largely similar. In rural communities, the majority of the population work as farmers or diggers. With such physically demanding and low paying jobs, adults develop severe back pain, which typically brings them to 
KIHEFO's clinics. Other common issues are lower abdominal pain (which usually coincides with back pain), urinary tract infections, pelvic inflammatory disease, scabies, and child and adult malnutrition.

\subsection{Malnutrition, Food Security, and Rabbit Breeding in Kabale}

Children under age five typically suffer the most from malnutrition. Child malnutrition can lead to wasting and stunting. Wasting and stunting are both indicators of moderate malnutrition. Wasting occurs when a child has a low weight for their height and stunting occurs when a child has a low height for their age. When KIHEFO staff identify families that have malnourished children during outreach clinics, they advise them to attend KIHEFO's nutrition clinic held once a month in Kabale-town. Although traveling to Kabale-town can be a far journey for some families, parents prioritize this and at least 50 children attend the nutrition clinic every month. The nutrition clinic gives children a nutrition assessment by assessing their height, weight, and mid-upper arm circumference (MUAC), which determines if a child is malnourished. The clinic also offers breakfast and lunch for the attendees and classes on how to eat a balanced and nutritious diet in an economically feasible way. These classes are intended to prevent the reoccurrence of malnutrition at the household level in rural communities. In a study conducted by Sswanya and Ahmadi-Esahan (2000), it was found that households in rural Uganda derive between $30 \%$ of their iron, $40 \%$ of their food energy, $60 \%$ of their protein intakes from starchy staples. While starchy staples provide necessary calories, they lack the micronutrients needed to fight malnutrition. By providing nutrition classes, KIHEFO is helping to teach families how to provide a well balanced diet for their children and fight malnutrition.

When the nutrition clinic began, the number of patients was overwhelming. Dr. Anguyo remembers people lining up around the block to be assessed. The doctors at the general clinic would become overwhelmed because children had a plethora of other health issues that they needed to be treated for as well. (G. Anguyo, personal communication, March 6, 2018). Dr. Allen Obiale, the head of the general clinic, recalls that children were not only malnourished, but also suffering from ailments such as

respiratory infections, diarrhea, and gastrointestinal diseases. Unfortunately, KIHEFO couldn't provide all of the treatment necessary because they had a limited supply of drugs and doctors. Furthermore, since the children came from rural communities they needed medical services for free, which put an additional stress on the clinic. Due to the high prevalence of malnutrition and the demand at the nutrition clinic, KIHEFO looked for alternative solutions to solving malnutrition in a sustainable, integrated, and innovative way. Since KIHEFO began to address issues of malnutrition differently, the need for health services and the prevalence of malnourished children in the Kabale district has drastically decreased (A. Obiale, personal communication, March 3, 2018). 
KIHEFO's solution to addressing issues of malnutrition and food security was to develop a rabbit breeding program in addition to the health clinics and outreaches they provide. The program has been overwhelmingly successful. Since the program was founded in 2011, hundreds of families in rural communities have received rabbits to breed, sell, and eat. Dr. Anguyo founded the rabbit breeding project as a way to fight poverty and malnutrition in Kabale district. With rabbit breeding, "people can generate income and at the same time have high quality protein, which is very, very insufficient in Kabale" (G. Anguyo, personal communication, March 6, 2018). Rural families have been able to feed their children, buy necessary household items, and send their children to school as a result of breeding rabbits. It is clear through these successes that rabbit breeding perfectly compliments KIHEFO's mission of fighting disease, poverty, and ignorance in Kabale.

KIHEFO chose to breed rabbits for a number of reasons. First of all, rabbits have a short gestation period of just one month. Many of the KIHEFO staff regard this as one of the biggest successes of the rabbit breeding project. A female rabbit can breed about six to eight times a year, and each time she can produce between six and eight rabbits per litter. Therefore, one rabbit can produce up to 64 rabbits per year, which can drastically improve a rural family's livelihood. KIHEFO typically donates two female rabbits and one male rabbit to a family when they are starting a breeding project. From just those three rabbits they can produce up to 128 rabbits in a year, a great bonanza in terms of protein and income.

Families are encouraged to both eat and sell their rabbits. If that family eats rabbit every month, or 12 rabbits a year, there are still 116 rabbits left over. One rabbit sells for between 10,000 and 12,000 Ugandan shillings (or between \$2.10 and \$3.30 USD) on the market. A rural family can have an income of between 116 million and 139 million Ugandan shillings (\$313.20 to \$375.84 USD) a year from reproducing the rabbits donated by KIHEFO. That income can greatly improve a rural family's livelihood and food security. Two of the six beneficiaries interviewed identified as casual laborers. In exchange for their labor, people either get some of the crops they harvested to feed his family, or 7,000 Ugandan shillings ( $\$ 1.89$ USD). Barnabas Arinawe, a casual laborer in the Kabale district reports that 7,000 shillings is a fair price for a day's work in someone else's field. (B. Arinawe, personal communication, March 14, 2018). Such income is right around the global poverty line of $\$ 1.90$ a day as established by the World Bank (2015). However, considering that the income earned by casual laborers is not guaranteed everyday, this places casual laborers in rural Uganda far below the World Bank's poverty line. For someone living at the World Bank's poverty line of $\$ 1.90$ per day, food would account for some 50-70\% of income (Sundaram \& Elver, 2016). In this context, the sale of rabbits becomes an important source of income with the potential to lift households out of poverty.

Secondly, rabbits require very few inputs, which makes starting a rabbit project easy for rural families. Previous animal breeding projects in Uganda, such as chicken and piggery projects, failed due to 
lack of resources. The government attempted to donate chickens and pigs to rural families, but the animals died. Chickens and pigs require special feeds which can be expensive. Put simply, if a family is unable to feed themselves, they are not going to be able to feed their animals. Unlike chickens and pigs, which require expensive feeds, rabbits will eat any kind of weed, grass or plant. Therefore, rabbit breeding is the most sustainable type of animal breeding for rural Ugandan families because it requires no monetary expenses from the family breeding the rabbits.

Third, rabbit urine and feces can be used on a family's farm as pesticide and fertilizer, respectively. This benefit helps to create a cycle of on-farm inputs that benefit rabbit breeding and food security. Essentially, the rabbit helps to grow the weeds that it eats. It also helps to grow other crops, which can increase a family's food security. Multiple rabbit beneficiaries reported seeing an improvement in their crops due to the manure and commented on the advantages of having their own manure. This reduces the amount of money that a family has to spend on fertilizers, money they can then spend on meeting other needs. The same can be said for the use of rabbit urine as pesticide. Using rabbit urine as pesticide is a simple and sustainable way to protect the integrity of crops.

Finally, the market for rabbit meat is growing in Uganda. In the last few years in Kabale three 'rabbit joints,' restaurants that sell rabbit meat, have popped up. Businesspeople in the area have seen how rabbit breeding and consumption has grown in popularity and capitalized on it. Ultimately, this has been effective for both the urban businessmen and the rural rabbit breeders. For example, the owner of the Manhattan Hotel in Kabale started a rabbit joint in the lower level of his hotel. In order to get a consistent supply of rabbits in his hotel he also started a mini rabbit breeding center in the village where he came from. Nowadays, people from that community breed rabbits and sell them to the hotel owner consistently. When he goes out to the community to purchase rabbits, he also brings supplies from town like soap to sell to them in the trading center there. The businessman makes a profit, and the community members are able to purchase necessary goods and sell their rabbits without having to travel. Dr. Anguyo hopes that one day the Kabale region will be known for rabbit and will be able to attract tourists who are interested in tasting the region's rabbit (G. Anguyo, personal communication, March 6, 2018).

Rabbit beneficiaries are identified through various avenues, but mainly through KIEHFO clinics. KIHEFO's monthly nutrition clinic provides health and food education and supplementation services to children under five who suffer from malnutrition. Parents and their children are invited to the nutrition clinic in Kabale-town on the last Saturday of every month to get a health assessment, medication if necessary, a nutrition and cooking class, and to share meals. Families with children who are severely malnourished are identified during these clinics and prioritized as rabbit beneficiaries. KIHEFO also identifies beneficiaries through their HIV clinic, since HIV and malnutrition greatly influence each other. 
KIHEFO targets people with multiple issues to be rabbit beneficiaries, in an attempt to help the most vulnerable first. For example, families with malnutrition and HIV will be given rabbits before other people in their community. Of the rabbit beneficiaries interviewed, half of the head of households were HIV positive. Five out of six of the beneficiaries interviewed claimed that issues of food security or malnutrition were significant household challenges prior to rabbit breeding. All of the beneficiaries noted that having a source of protein was a benefit of rearing rabbits.

Once a family is identified, KIHEFO will donate one male and two female rabbits to a family without fees. The only condition to receiving rabbits from KIHEFO is that the family has a hutch where the rabbits can live. When families are unable to provide a hutch for themselves, which often happens amongst the poorest populations, KIHEFO will donate a hutch. KIHEFO works to provide hutches to the most vulnerable first, and then expand to other people in need in rural communities. Previously, rabbits would live loose within a family's compound, with no housing. This proved ineffective because the rabbits would burrow into the ground, becoming wild, and disturb a family's home and crops. It can be difficult for a poor family to build a hutch because construction inputs can be expensive. When funding allows it KIHEFO donates a hutch to the beneficiary family in addition to the rabbits. When KIHEFO donates rabbits to a family, it requires that the family give away three of the rabbits from their first litter to another family in need in their community. That second family is then required to donate three of the rabbits from their first litter to another family in their community, and so on. In other words, the first family who got the rabbits directly from KIHEFO are expected to be a resource for other families in their community and provide training when needed. This model sustainably spreads rabbit breeding throughout a community without extensive involvement from KIHEFO.

\subsection{Successes and Challenges of Rabbit Breeding in Kabale}

KIHEFO has been very successful in raising awareness of the benefits and potential of rabbit breeding. Before they founded the rabbit breeding project in 2011, virtually no one was rearing rabbits in the Kabale district. Now that people are aware of the successes of rabbit breeding, it is becoming a more accepted project in the area. Rabbit beneficiaries are grateful to KIHEFO for helping them provide for their families. They speak passionately about the successes of their rabbit breeding projects and their desire to expand them. It is clear through KIHEFO's work in the Kabale district that rabbit breeding has the potential to greatly improve the livelihood status of individual households as well as the community as a whole.

Rabbit breeding mainly helps people in the Kabale district by providing them a source of income and a source of protein. All of the rabbit beneficiaries interviewed had children or grandchildren living with them, and use the income they make with rabbit breeding to provide for these children. Margaret 
Neema, the manager of the HIV clinic, specifically commented on how helpful rabbit breeding is for households that are just made up of grandchildren and grandparents. Many grandparents have had to care for their grandchildren due to high levels of HIV/AIDS related death. Because of the fragility of grandparents, these households are particularly vulnerable. Unlike households with able bodied parents, grandparents lack the ability to work in the field and provide an income for their households (M. Neema, personal communication, March 2, 2018).

Given the high number of children in Uganda, every beneficiary interviewed noted that they used some of the income from rabbit breeding to pay for school fees. Dr. Anguyo asserts that probably a family has sent a child to university thanks to the income from rabbit breeding, although a more robust assessment of the program is needed to fully support this (G. Anguyo, personal communication, March 6, 2018). Supporting education helps KIHEFO in its goal to fight ignorance in the Kabale region. Barnabas Nabaasa, the manager of KIHEFO's rabbit breeding program, comments on how ignorance can be deadly because people do not always know about the availability of basic health services, such as family planning. Ignorance can worsen health in rural communities since people do not know what is available to help them (B. Nabaasa, personal communication, March 9, 2018). Other uses of the income were other food items (such as rice, posho, and beans), other livestock (like chicken, pigs, goats, and cows), household items (like soap, salt, and toilet paper), scholastic materials, and hiring labor for a family's farm. These items help to improve a household's material and non-material well being.

According to KIHEFO staff members, good nutrition is essential for living a healthy life. Claire Atuhaire, the manager of the nutrition clinic, claims that poverty is the biggest driver of malnutrition. If a family is unable to provide adequate food for their family, they will experience malnutrition, which is likely to lead to additional health issues. Furthermore, if a family cannot provide food for their family, they are unlikely be able to afford medical services (C. Athuhaire, personal communication, March 6, 2018). We can assume that the general health of a family facing malnutrition will be poor. For families that have started rabbit breeding, the KIHEFO general clinic has seen a decrease in health issues besides malnutrition. For example, they have seen fewer cases of opportunistic infections, respiratory infections, and diarrhea. Sharon Magalla, a rabbit beneficiary, reported that since breeding rabbits her children haven't had worms, which is an additional positive health outcome (S. Magalla, personal communication, March 7, 2018).

Carol Kyampiere, a social worker at KIHEFO notes that poverty and poor health go hand in hand. In fact, she calls it a "vicious cycle of poverty." (C. Kyampiere, personal communication, March 6, 2018). A sick family member most likely does not have the energy to go work in the garden or field and provide for their family, and consequently the household's livelihood suffers. As previously noted, nutrition status is especially important when a patient has HIV. Treatement for HIV with antiretroviral drugs (ARVs) 
requires a complete, balanced, and nutritious diet. Certain ARVs make patients extremely hungry and they need to eat with their medications. When patients do not have sufficient access to food, they often stop taking their drugs. This can lead to bigger problems like drug resistance and exemplify patient's struggles with HIV. Furthermore, eating well while taking ARVs increases the effectiveness of ARVs. Rabbit meat, which is especially helpful in boosting the immune system, can help people fight HIV (M. Neema, personal communication, March 2, 2018).

One of the biggest issues concerning food security and nutrition in rural areas near Kabale-town is poor food storage alternatives (G. Anguyo, personal communication, March 6, 2018). Outside of harvest seasons it is hard to have food to feed a household because food stores so poorly. Rabbit breeding can be a solution to that problem. When a family lacks food reserves they can eat rabbit meat and sell rabbit meat, and with the proceeds buy supplementary food items. Remegio Asuuru, a rabbit beneficiary, commented that thanks to his rabbit breeding project he never has to worry about food. If his crops fail, he can simply sell some of his rabbits and buy food for his family (R. Asuuru, personal communication, March 14, 2018). This shows the benefits of diversifying household livelihoods. By not relying on one source of income, household's are able to reduce their vulnerability context, which can improve their livelihood.

The main issues that rabbit breeders faced after obtaining rabbits were theft and rabbits getting sick and dying. Four beneficiaries reported having problems with thieves and three reported having issues with disease and death. Over time, KIHEFO has addressed both of these problems in the communities where it works. Rabbit beneficiaries are now provided with padlocks to keep their rabbits secure. Since the introduction of padlocks, none of the beneficiaries with locks have had problems with theft. They have also addressed the issue of sickness and death by training community members on the basics of rabbit breeding and advising newer beneficiaries to consult with previously trained breeders. Sharing knowledge this way is less demanding for KIHEFO and empowers people in rural areas to take control of the development in their communities.

The main challenge that KIHEFO has with the rabbit breeding program is data collection and follow up with the rabbit beneficiaries. It is estimated that there are over 2,000 families breeding rabbits in the Kabale region. However, due to expensive transportation costs and lack of funding to evaluate project success, this number is only a rough estimate. According to Dr. Anguyo, KIHEFO donates rabbits to about five families every month. However, some months there are more and some months there are less beneficiaries. There is virtually no documentation about these donations. Furthermore, there is no documentation regarding beneficiaries who stop breeding rabbits, or about beneficiaries giving rabbits to other community member, so there is no sense of the overall impact and expansion of rabbit breeding in Kabale (G. Anguyo, personal communication, March 6, 2018). Proper data collection would help 
KIHEFO in a number of ways. For example, having accurate documentation on the successes of rabbit breeding can attract donors. Currently, KIHEFO lacks this data and concrete proof on the successes of the rabbit program. Finding donors and investors can help expand KIHEFO's rabbit project, and make the benefits of rabbit breedings a reality for increasing numbers of people.

\subsection{Rabbit Breeding as a Sustainable Livelihood Approach to Development}

Small-scale rabbit production is a form of sustainable rural development that is gaining global

The ideal small-scale rabbit production model (SSRPM) represents an alternative and self-supporting system, based on renewable farm resources, that embodies the great potential for achieving a favorable, sustained impact (chiefly nutrition and economic) on limited-resource farm families who are mostly in lesser-developed countries.

recognition. According to Lukefahr (2004),

Here, Lukefahr places SSRPM in context. Rabbit breeding is ideal for limited-resource farm families, which is why KIHEFO has chosen this as a development tool. Lukefahr (2004) claims, and KIHEFO

A salient feature of the SSRPM is that sustainable measures can be readily adopted by the limitedresource farmer, which also lends themselves well to diversification (combination of other crop and livestock activities) to further ensure food and economic security. In contrast, in commercial operations it is oftentimes simply not feasible to maintain sustainable or diversified systems due to labor and (or) economic nnnomininte

proves, that rabbit breeding works much better in rural rather than urban settings. Lukefahr (2004) notes: The benefits of diversification of livelihood activities was previously noted by Asuuru. Clearly, SSRPM is an effective tool for sustainable livelihood development.

Although rabbit breeding offers economic opportunities, KIHEFO still primarily promotes subsistence farming and rabbit breeding, as opposed to intensification and commercialization. KIHEFO has a large-scale, fairly commercial rabbit breeding center just outside of Kabale-town. At the center they train people on how to breed rabbits as a business venture, like the owner of Manhattan Hotel. They also 
train people who are developing a rabbit breeding program as a business venture on creating a mini breeding center so that they can sell rabbits to other people who want to profit from hem. As opposed to donating rabbits to rural families, the rabbit breeding center focuses on the commercialization of rabbits. Those who receive training on rabbit breeding as an economic venture must pay a small fee to KIHEFO to keep the project going. Although KIHEFO has commercialized some aspects of their rabbit breeding program, that is not the end goal. However, they do encourage their beneficiaries in rural communities to commercialize their rabbit breeding.

According to Lukefahr (2004), sustainability as applied to rabbit farming could be defined as "the continuous supply of rabbit meat, supported by renewable and natural on-farm resources, and produced from an integrated and diversified enterprise that benefits the farm family and the community with respect to the provision of nutritious meat and supplemental income". Clearly, the benefits of rabbit breeding extend far beyond economic gains. KIHEFO promotes the breeding of rabbits first and foremost as a source of protein because the overall goal of the rabbit breeding project is to eradicate malnutrition. Selling rabbits and generating income comes second. Without rabbit breeding rural families would rarely eat meat. Many of the beneficiaries interviewed reported eating meat once or twice a year, on Christmas and Easter, before they had a rabbit breeding project. Now, with rabbits in their backyard, rural families typically eat rabbit once a month.

Consuming rabbits helps with food security in several ways. First of all, it offers a source of protein to communities, when otherwise protein would be too expensive. In a study conducted by Sswanya and Ahmadi-Esahan (2000), it was found that households in rural Uganda derive between $30 \%$ of their iron, $40 \%$ of their food energy, $60 \%$ of their protein intakes from starchy staples. This demonstrates a nutritional imbalance, and possibly an explanation of malnutrition.

The lack of protein supply in rural communities is due to poverty. A kilo of meat costs roughly 10,000 shillings, but rural farmers rarely make that much money in a day. As previously stated, casual laborers make 7,000 Ugandan shillings a day when there is work. Clearly, buying meat consistently is extremely difficult for poor, rural farmers. However, rabbit breeding secures families with a source of meat. If they ever want or need to eat meat, they can simply pluck a rabbit from their cage and eat it.

Additionally, rabbits provide a source of income, which many families use to buy food staples. Sometimes these compliment rabbit meat, and other times they are used as the main source of food. As previously stated, a rural family can make up to 139 million Ugandan shillings, or \$375.84 USD, from just two rabbits each year. Every single rabbit beneficiary interviewed reported spending some of the income from rabbit breeding projects on other food items, such as beans, rice and posho. Additionally, all of the beneficiaries interviewed used some the income from the rabbit project to pay school fees for their children. Investing in education helps break the cycle of poverty in rural communities. In the sustainable 
livelihood approach, investing in education increases a household's social and human capital, which can lead to more desired livelihood outcomes. Hence rabbit breeding can be used as a tool for sustainable livelihood development.

Rabbit breeding has proven to be an effective development tool in Kabale, Uganda and in other areas of the world. Rabbit breeding helps provides protein and income to rural households, which helps fight malnutrition and poverty, as well as other problems. In Kabale, staff members of KIHEFO have seen a drastic improvement in the health of children and adults in rural communities, and attribute the success to rabbit breeding. However, there is still room to grow for rabbit breeding as a tool for sustainable development. In Kabale specifically, there needs to be better documentation and analyzation in order to show how successful the project is.

In the future, KIHEFO hopes to expand the rabbit breeding project. Many of the staff members dream of seeing rabbit breeding projects in every home in the Kabale district. Dr. Anguyo is determined to set up a rabbit processing plant once he secures funding. The processing plant would increase the supply of rabbit meat and hopefully expand the market for rabbit in the country. Dr. Anguyo and Goretti Lietru hope to improve the utilization of fur. Currently, rabbit skin and fur is thrown away. However, there is great potential for both of them. For example, rabbit skin can be used to make rabbit sausages (G. Lietru, personal communication, March 10, 2018). Using all of the parts of the rabbits also increases the sustainability of rabbit breeding by reducing waste.

\subsection{Conclusion}

Over the years, there have been many different strategies to international development, some more successful than others. Rural development, poverty alleviation, and food security are development topics that are of growing international importance. The sustainable livelihood approach to development offers a holistic approach to development. It addresses the assets that households have and works to improve and build upon them.

The sustainable livelihood approach can be seen in rural Uganda with an organization known as KIHEFO. KIHEFO began as a health clinic and since it has expanded to address issues of food security in its community. Now, in addition to the health clinics, KIHEFO also has a rabbit breeding program that helps rural communities improve their livelihoods. Rabbit breeding provides rural households with a source of protein and income, two things that are vastly needed among resource-limited people.

KIHEFO's success with rabbit breeding shows how valuable a comprehensive approach to development can be. Thanks to rabbit breeding, the Kabale region has seen a significant decline in malnutrition among children and adults, more children have been able to go to school, rural incomes have increased, and 
household food security has improved. Clearly, approaching development through various avenues has proven effective.

For rabbit breeding to expand across Uganda, there needs to be improved data collection and analysis. By documenting the successes of rabbit breeding, KIHEFO can attract donors and increase its funding. Future research could focus on how rabbit breeding improves the livelihoods of people affected by HIV. This would help significant numbers of people living in Uganda due to the high prevalence of HIV in the country.

All in all, approaching development in a sustainable, innovative, and integrated way, like KIHEFO strives to do, is an extremely effective approach. This approach has the potential to improve the livelihoods of the most vulnerable. In Uganda, where $80 \%$ of the population lives in poverty, in rural areas and relies on agriculture for their livelihood, this approach is much needed. KIHEFO's mission, to provide sustainable, innovative, and integrated health care proves to be successful and result in positive outcomes. 


\section{References}

Ahaibwe, G., \& Mbowa, S. (2014). Youth Unemployment Challenge in Uganda and the Role of Employment Policies in Jobs Creation. Brookings. Retrieved from https://www.brookings.edu/ blog/africa-in-focus/2014/08/26/youth-unemployment-challenge-in-uganda-and-the-role-ofemployment-policies-in-jobs-creation/

Andersson, E., \& Gabrielsson, S. (2012). 'Because of poverty, we had to come together': Collective action for improved food security in rural Kenya and Uganda. International Journal of Agricultural Sustainability, 10(3), 245-262.

Apili Ejupu, E. C., Makhura, M. T., \& Kirsten, J.F. (1999). Food security in a commercialising rural economy: Initial findings from a case study of two districts in Uganda. Agrekon, 38(4), 827-838.

Baro, M., \& Deubel, T. (2008). Persistent hunger: Perspectives on vulnerability, famine, and food security in sub-saharan Africa. Annual Review of Anthropology, 35, 521-538

Bukusuba, J., Kikafunda, J. K., Whitehead, R. G. (2007). Food security status in households of people living with HIV/AIDS (PLWHA) in a Ugandan urban setting. British Journal of Nutrition, 98, 211-217. 
Burchi, F., Frison, E., \& Fanzo, J. (2011). The role of food and nutrition approaches in tackling hidden hunger. International Journal of Environmental Research and Public Health, 8, 358-373.

Bryceson, D.F. (2009) Sub-Saharan Africa's vanishing peasantries and the specter of a global food crisis. Monthly Review, 61(3), 48-62.

Chambers, R. \& Conway, G. (1991). Sustainable rural livelihoods: Practical concepts for the 21st century. Retrieved from https://opendocs.ids.ac.uk/opendocs/bitstream/handle/123456789/775/Dp296.pdf? sequence $=1 \&$ isAllowed $=\mathrm{y}$

Children, Nutrtition, and Food Security. (n.d.). In Kigezi Healthcare Foundation. Retrieved from http:// www.kihefo.org/children-nutrition-food-security/

Ellis, F., \& Bahiigwa, G. (2003). Livelihoods and rural poverty reduction in Uganda. World Development, 31(6), 997-1013.

FAO. (2008). An introduction to the basic concepts of food security. Retrieved from: http://www.fao.org/ docrep/013/al936e/al936e00.pdf

FAO. (2017). The state of food security and nutrition in the world 2017. Retrieved from: http:// www.fao.org/state-of-food-security-nutrition/en/

Feed the Future. (2018). Uganda Country profile. Retrieved from: https://www.usaid.gov/what-we-do/ agriculture-and-food-security/increasing-food-security-through-feed-future

Government of Uganda (2001). Plan for modernization of agriculture: Eradicating poverty in Uganda. Retrieved from http://www.inclusivebusinesshub.org/wp-content/uploads/2016/05/ PMAMaindocument.pdf

Krantz, L. (2001) The Sustainable Livelihood Approach to Poverty Reduction. Retrieved from https:// www.sida.se/contentassets/bd474c210163447c9a7963d77c64148a/the-sustainable-livelihoodapproach-to-poverty-reduction_2656.pdf

LIFT. (2013). Livelihood and food security conceptual framework. Washington, DC: Gary Woller. 
Lukefahr, S. D. (2004). Sustainable and alternative systems of rabbit production. Proc.: 8th World Rabbit Congress. Puebla, Mexico.

Martiniello, G. (2015). Food socereignty as praxis: Rethinking the food question in Uganda. Third World Quarterly, 36(3), 508-525.

Maslow, A. H. (1943). A theory of human motivation. Psychological review, 50(4), 370.

Ministry of Finance, Planning, and Economic Development. (2001). Poverty Reduction Strategy Paper (PRSP) Progress Report 2001. Retrieved from http://siteresources.worldbank.org/INTPRS1/ Resources/Country-Papers-and-JSAs/uganda_ppr.pdf

Mohan, G. (2014). Participatory development. In V. Desai \& R. B. Potter. (Eds.), The companion to development studies (131-136). New York, NY: Routledge.

Oxfam Canada. (n.d.). There is enough food to feed the world. Retrieved from: https://www.oxfam.ca/t here-enough-food-feed-world

Oxfam. (2017). Embedding Food Security within Sustainable Livelihood Programs. Retrieved from https://policy-practice.oxfam.org.uk/publications/embedding-food-security-within-sus tainable-livelihood-programmes-316458

Shah, A. (2013). Structural adjustment: A major cause of poverty. Global Issues. Retrieved from http:// www.globalissues.org/article/3/structural-adjustment-a-major-cause-of-poverty

Smallman, S., \& Brown, K. (2015). Introduction to international and global studies. Chapel Hill, NC: The University of North Carolina Press.

Ssewanyana, S. N., \& Ahmadi-Esfahani, F. Z. (2010). Household food security in rural Uganda: A statistical analysis. Ecology of Food and Nutrition, 40(2), 93-125.

Sundaram, J. K., Elver, H. (2016). The world produces enough food to feed everyone. So why do people go hungry? Retrieved from https://www.weforum.org/agenda/2016/07/the-world-producesenough-food-to-feed-everyone-so-why-do-people-go-hungry 
Thompson, A. M. (2001). Food security and sustainable livelihoods: The policy challenge. The Society for International Development, 44(4), 24-28.

Tsai, A. C., Bangsberg, D. R., Emenyonu, N., Senkungu, J. K., Martin, J. N., Weiser, S. D. (2011). The social context of food insecurity among persons living with HIV/AIDS in rural Uganda. Social Science Med, 73(12), 1717-1724.

Uganda Bureau of Statistics. (2018). Unemployment Rates of Youth in Uganda. [Statistical dataset]. Retrieved from https://www.ubos.org/explore-statistics/statistical-datasets/5832/

UNAIDS. (2008). HIV, food security, and nutrition. Retrieved from: http://www.unaids.org/sites/default/ files/media_asset/jc1565_policy_brief_nutrition_long_en_0.pdf

WFP. (2018). WFP Uganda Country Brief.

World Bank. (2015). World Bank Forecasts Global Poverty to Fall Below 10\% for First Time; Major Hurdles Remain in Goal to End Poverty by 2030. Retrieved from http://www.worldbank.org/en/ news/press-release/2015/10/04/world-bank-forecasts-global-poverty-to-fall-below-10-for-firsttime-major-hurdles-remain-in-goal-to-end-poverty-by-2030.

World Hunger Organization. (2016). 2016 World Hunger and Poverty Facts and Statistics. Retrieved from: https://www.worldhunger.org/2015-world-hunger-and-poverty-facts-and-statistics/

Zoomers, A. (2014). Rural livelihoods in a context of new scarcities In V. Desai \& R. B. Potter. (Eds.), The companion to development studies (230-234). New York, NY: Routledge. 